\title{
The Impact of Continuous Education on Intellectual Capital and Market Value of Companies: A Work-In-Progress Paper
}

Luís Filipe Pinheiro Mesquita Diniz School of Economics and Management, University of Minho, Braga, Portugal

\section{Eduardo Tomé}

University Europeia, Lisbon, Portugal

\begin{abstract}
The rapid pace of technological innovation, globalisation and the subsequent intensified market competition have promoted the growth in the demand for, and supply of, competent workforce. Knowledge and innovation are perhaps more important than the tangible assets of a company. Every organisation has intangible assets which they do not report on their balance sheet. The rise of knowledge economy signals the growing importance of intangible assets, namely intellectual capital. For some businesses, intellectual capital is probably the key driver of value creation. Thus, knowledge constitutes the dominating resource in knowledge-oriented companies. This paper focuses on the theme of continuous education and its repercussion on the intellectual capital of companies as well as on its market value. Thus it aims to analyse the existing correlations between these variables.
\end{abstract}

Paper type: Work-In-Progress paper

Keywords: Intellectual Capital, Knowledge, Intangible Assets, Continuous Education, Company Market Value. 


\section{Introduction}

It is widely accepted view that the skills of the workforce do not well-match with the ongoing business needs. This is mainly due to intensified market competition, technological advances, uncertainties associated with the market changes, and inadequate training and development. It has thus become necessary to critically examine the role of Continuous Education (CE) in developing the intellectual capital (IC) of companies. Human resources constitute to an essential element to achieve competitive advantage in organisations (Barney, 1991). However, skills may become obsolete in a rapidly changing business environment. Wan et al. (2012: 308) found that approximately 50\% of all types of skills and knowledge possessed by human resources become obsolete within five years. It is therefore imperative for organisations to equip their employees with necessary skills in order to be prepared to manage change. There is evidence that expenditure on training and development is steadily increasing. Companies throughout the world spend about 100 billion dollars annually on training their employees in order to improve their skills and performance (Desmet et al., 2010).

Intellectual assets play an important role in the present-day corporate world since they represent future expected benefits. Thus, our interest resides in critically raising issues regarding the impact of investment in continuing education on the intellectual capital of companies and its market value, besides considering human resources as being the most important element in companies. According to Daum (2003), there is an ever-widening gap between the market value and book value of companies, and this difference can be explained by IC (Brennan and Connel, 2000). This study could contribute to a justification of the present difference between these two concepts. A deeper understanding of this interaction may potentiate the growth of intellectual capital in companies.

In light of the above, this study aims to:

1. Evaluate the pertinence of lifelong CE with a view to building IC in companies;

2. Demonstrate the importance of IC as a value aggregating factor for companies;

This paper analyses the following question: What is the repercussion of continuous education on intellectual capital and the market value of companies?

This paper has three sections. In section 2, we analyse the concepts that are relevant for the paper; in section 3 we describing the main theories that relate $\mathrm{CE}$ and IC with the value of a company, and we define hypothesis. In section 4 we define a methodology to use in a practical study. Finally, in section 5 we present the paper's final comments.

\section{Literature Review}

In this section we review the paper's main concepts: continuous education (Section 2.1), knowledge (Section 2.2), and intellectual capital (Section 2.3). 


\subsection{Continuous Education}

Continuous Education (CE) is a way of investing in the knowledge and skills of human resources ( $\mathrm{Ng}$ and Dastmalchian, 2011; Davis et al., 2006) and corresponds to learning provided with the purpose of improving performance in the workplace (Mehra and Mookerjee, 2012). Levy (2005) described an emerging trend that creates leverage for both organisations and individuals: the fourth revolution. For Levey (2005), the fourth revolution is about developing the full potential of knowledge workers, allowing them to do less but accomplish more and thereby gaining maximum return on human capital.

In Germany, continuous on-the-job training is widely recognised as an important mechanism to develop and maintain competent workforce (Georgellis and Lange, 2007). CE is not a oneoff investment; rather it requires continuous efforts to monitor and evaluate (Huang and Jeong, 2011). CE can thus be seen as lifelong training, which takes place after initial training, involving all subjects in the labour market (Cardim, 2005). In Portugal, the Interministerial Commission for Employment (CIME) drew up a document in which, among others, a definition of Professional Training was included. This was understood to be a set of activities directed at the acquisition of knowledge, skills, attitudes and the types of behaviour demanded by the performance of tasks inherent to a profession or set of professions in any area of economic activity. The proposal of improvement, or $\mathrm{CE}$, aims to prepare workers as assets, in the sense of improving their professional skills at all levels of qualification, updating knowledge, promoting adaptation to technical and organizational transformation (Cardim, 2005).

\subsection{Knowledge}

We all are, as the saying goes, standing on the shoulders of giants. To a large extent, each new piece of empirical research will essentially be based upon the existing literature. Knowledge built upon theories and collective effort. As such, knowledge evolves constantly (Sveiby, 2000) and knowledge sharing influences the productivity and efficiency in a positive way (Spender, 1996). To be useful, the knowledge needs to be disseminated by the company (Arnett and Wittman, 2014). In reference to North (2010), for a knowledge-oriented company to be successful, one needs to know how to transform individual knowledge into collective knowledge and vice-versa. Knowledge creation in an organisational context implies the integration of individual perspectives into a new collective (Nonaka, 2007). However, knowledge resides within people and it is inseparable from people (Loureiro, 2003). It is therefore impossible to disseminate knowledge without interactions among the knowledge workers. For that reason, it is necessary to understand the process of knowledge sharing and the implications of continuous education to the intellectual capital of organisations.

In the knowledge economy where "the only certainty is uncertainty" (Nonaka, 2007: 96), knowledge could be the key to sustainable competitive advantage. To sustain in the competitive business environment, companies need to draw their attention to two essential elements: 1) the importance that each individual worker's knowledge contributes to the company; 2) the company should have collective consciousness with respect of knowledge and its importance in terms of knowledge sharing by the means of technology or other ways

International Journal of Management and Applied Research, 2014, Vol. 1, No. 2 
with the purpose of improving the performance of its human resources and, consequently, the company's productivity (Levy, 2005: 64).

Brooking (1996) divides knowledge into three categories: tacit knowledge, explicit knowledge, and last but not least, implicit knowledge. Explicit knowledge is easily shared since it is formal, systematic, and exists in an articulated form (Nonaka, 2007). Examples of explicit knowledge include financial reports, manuals, and textbooks. On the other hand, tacit knowledge is difficult to share, explain and transcribe. Tacit knowledge is difficult to formalise and transfer since it is highly personal. According to North (2010), tacit knowledge represents each individual's personal knowledge which is based on each person's ideas, intuition and values. It is subjective and is directly related to each person's own experiences. In reference to Stewart (1999), tacit knowledge is oral and spontaneous; it does not require long reasoning times and cannot be found in books or data bases. It is thus important for companies to recognise and appreciate the key personnel who possess tacit knowledge in the companies. Implicit knowledge is a type of "covert" knowledge and is related to the operational part of a company and company culture.

Nonaka (2007) simplified the type of knowledge into two: explicit and tacit knowledge. For Nonaka (2007), there is a need to translate tacit knowledge into explicit knowledge, making knowledge easily transferable within and across an organisation. In short, as Stewart (1999) states, it has become fundamental in companies to decide what constitutes or does not constitute useful important knowledge, which is susceptible to creating value for organisations.

\subsection{Intellectual Capital}

For Davenport et al., (2003:59), there is a new company "hero": the man who brings along new ideas. He was the first person to proffer the expression "intellectual capital" for the first time and believes that a better management of intangible assets brings a competitive edge to companies. IC lacks of universally accepted definition (Tseng and Goo, 2005). It is a multidisciplinary concept, involves different areas related to business (Huang et al., 2007). For Tseng and Goo (2005), the theoretical origins concerning IC are based on two schools of thought: the strategic current and the measurement current. The measurement current deals with the creation of a new mechanism of dissemination, which allows for the measurement of qualitative non-financial information. This is undertaken in the same manner as quantitative and financial data are measured. On the other hand, the strategic current focuses on the creation of value, on the study of factors which enable value creation.

Intellectual Capital (IC) is often seen as intangible value of a company which includes a set of intangible assets not typically found in balance sheet. For Stewart (1999:14), "Intellectual capital consists of intellectual material - knowledge, information, intellectual property, experience which can be used to generate wealth". Intellectual capital comprises collective knowledge stemming from various sources of an organisation (Stewart, 1999). It is difficult to quantify the true value of an organisation due to the difficulty to measure the intangible, nature of intellectual capital. In the intellectual capital literature, the difference between the market value and book value of a company represents IC (Roos and Roos, 1997; Stewart, 1999; Stam, 2007; Tseng and Goo, 2005). Understanding the IC of an organisation allows the

International Journal of Management and Applied Research, 2014, Vol. 1, No. 2 
organisation to better anticipate its growth and leverage its key assets (Hermans and Kauranen, 2005).

IC can be broadly referred to a collection of intangible values of a business, ranging from its people (human capital), its network (relational capital), its facilities and enabling environment for knowledge transfer (Chen et al., 2014; Hermans and Kauranen, 2005; Kaplan and Norton, 2004; Mouritsen et al., 2005; Stewart, 1999; Tseng and Goo, 2005). A well-balanced of these primary components of IC would allow an organisation to create value through its business activities (Hermans and Kauranen, 2005; Garanina and Pavlova, 2011; Tseng and Goo, 2005). Human capital not only corresponds to the knowledge, skills and abilities of its human resources (Bontis et al., 2000; Hermans and Kauranen, 2005). Structural capital refers to the institutionalised knowledge that belongs to the company, which includes the physical assets, hardware, facilities, building, corporate image, patents, registered trademarks (Al-Khalil et al., 2014). Relational capital represents the value inherited in the relationships between its stakeholders including customers, suppliers, business partners (Guthrie et al., 2012; Hermans and Kauranen, 2005; Sveiby, 2000). An investment in human capital and structural capital creates more skilled workforce who then develop better relationships with key stakeholders, and consequently leading to increased market value.

\section{The Impact of Continuous Education on the Intellectual Capital and Value of a Company: Theories}

Having exemplified the concept of intellectual capital and continuous education, this paper now needs to demonstrate the link between them to enhance our understanding of intellectual capital and its relevancy to market value. The market value of a company is inseparable from its intangible assets. The market value of a company corresponds to the sum of its book value and intellectual capital (Tseng and Goo, 2005). Empirical evidences report that investment in intellectual capital would increase the market value of the company (Bassi and MacMurrer, 1998; Lev, 2004; Liao et al., 2011; Liu and Wong, 2011). Liu and Wong (2011) noted that investment in research and development is directly related to the number of patents. In a similar vein, Teh et al. (2008) observed that the quantity of branded products is positively related to market value of the companies.

On the basis of the above observations, the authors propose:

Proposition 1: Investment in employee continuous education has positive impact on the value relevance of the intangibles of the companies.

\section{The Portuguese Case}

Portugal gives a good account of an emerging knowledge economy due to the following reasons. First, the Portuguese government recognises the importance of human capital in developing a stable economy the European lifelong learning guidelines have been reinterpreted and adapted in the Portuguese context, result in an increasing trend of adult education provision in an attempt to catch up with other European numbers (Guimarães, 2013). Second, the Portuguese business environment has made considerable progress in recovering from economic crisis, attracting attentions from both domestic and foreign investors. Many Portuguese companies have been scrutinised in terms of their market value. 
Finally, Portugal started an ambitious structural reform programme in 2011, leading to a stegnthened public finance and the current account deficit has closed in 2014 (OECD, 2014). This indicates the growing competitiveness of Portuguese firms and thus there is a need to examine the impact of continuous education to the market value of the Portuguese companies.

In the following section we outline the methodology for analysing the Portuguese case (Section 4.1), and present the data and sample to be used (Section 4.2).

\subsection{Methodology}

A bibliographic review will be undertaken in relation to each of the variables being studied, namely continuous training, intellectual capital and company value. The study will consider the impact on the accumulated investment in training (intangible resource) on intellectual capital and company's value. We will choose the sum of accumulated investments in employee training as a main component of IC. We will examine the impact that accumulated investment on continuous education has on the relevance of IC on market value. This relevance will be measured using Tobin's Q, calculated as the market value of the company divided by the book value equity, and with the latter calculated as the difference between the total assets and liabilities. Tobin's Q can be used for making comparisons among firms (Tseng and Goo, 2005). We will consider the period (2011-2013). This model is simple linear regression.

\subsection{Data and Sample}

The study will focus on Portuguese companies quoted on the Portuguese Stock Market. The data needed to conduct this study will be obtained from the Commission of the Securities Market (CMVM) for the stock market value, and from websites of the companies and reports of the companies, for the spending on training. The accumulated investments will be obtained by means of the spending summary on the variable (investment in training) in the period (2011-2013) to moment $t$, depreciated by a percentage. The linear rates used are $15 \%, 20 \%$ and $30 \%$. There is a lag effect in human capital on the value of the intangibles. That is, the value of intangibles of a company will not be only influenced by the investments performed in period $\mathrm{t}-1$, but they will also be influenced by the outgoings in previous years. An accumulative annual depreciation rate $(15 \%, 20 \%$, and $30 \%)$ will be used to consider this effect.

\section{Final Comments}

Roos and Roos (1997) highlight the importance of measuring IC since IC reflects the future capacity of a company to generate profits. Restated, there is empirical evidences indicate the investment in intellectual capital result in improved market value (Liu and Wong, 2011). Equally, studies have also shown that investment in training results in an increase in worker productivity (Hansson, 2007; Black and Lynch, 2001) which, in turn, is translated into an increase in financial performance (Bassi and McMurrer, 1998) and market value (Coget, 2011). The growing number of literature in the field of intellectual capital shows an increase in interest in the area (Al-Khalil et al., 2014; Bontis et al., 2000; Brennan and Connel, 2000;

International Journal of Management and Applied Research, 2014, Vol. 1, No. 2 
Hermans and Kauranen, 2005; Huang et al., 2007; Tseng and Goo, 2005). This research is still at its early stage and we hope that our study will pave the way for conducting more empirical research in this area, especially in Portugal.

\section{References}

1. Al-Khalil, S., Dahiyats, S. and Al- Dalahmed, M. (2014), "Intellectual capital development and its effect on technical innovation in banks operating in Jordan", Journal of Management Research, Vol. 6, No. 1, pp. 212-238.

https://doi.org/10.5296/jmr.v6i1.4629

2. Arnett, D. and Wittman, C. (2014), "Improving marketing success: the role of tacit knowledge exchange between sales and marketing", Journal of Business Research, Vol. 67, No. 3, pp. 324-331. https://doi.org/10.1016/j.jbusres.2013.01.018

3. Barney, J.B. (1991), "Firm Resources and Sustained Competitive Advantage", Journal of Management, Vol. 17, No. 1, pp. 99-120. https://doi.org/10.1177/014920639101700108

4. Bassi, L. and McMurrer, D. (1998), "Training investment can mean financial performance", Training and Development, Vol. 52, No. 5, pp. 40-42.

5. Black, S. and Lynch, L. (2001), "How to compete: The impact of workplaces practises and information technology on productivity", Review of Economics and Statistics, Vol. 83, No. 3, pp. 434-445. https://doi.org/ 10.1162/00346530152480081

6. Bontis, N., Keow, W. and Richardson, S. (2000), "Intellectual Capital and Business Performance in Malaysian Industries", Journal of Intellectual Capital, Vol. 1, No. 1, pp. 85-100. https://doi.org/10.1108/14691930010324188

7. Brennan, N. and Connel, B. (2000), "Intellectual capital: current issues and policy implication”, Journal of Intellectual Capital, Vol. 1, No. 3, pp. 206-240.

https://doi.org/10.1108/14691930010350792

8. Brooking, A. (1996), Intellectual Capital, London: International Thomson Business Press.

9. Cardim, J. (2005), Formação Profissional: Problemas e Politicas, Lisboa: Universidade Técnica de Lisboa: Instituto Superior de Ciências Sociais e Politicas.

10. Chen, L., Danbolt, J. and Holland, J. (2014), "Rethinking bank business models: the role of intangibles", Accounting, Auditing \& Accountability Journal, Vol. 27, No. 3, pp. 563589. https://doi.org/10.1108/AAAJ-11-2012-1153

11. Coget, J. (2011), "Does national culture affect firm investment in training and development", Academy of Management Perspectives, Vol.25, No.4, pp.85-87. https://doi.org/10.5465/amp.2011.0134

12. Daum, Y. (2003), Intangible Assets and Value Creation, UK: John Wiley \& Sons. 
13. Davenport, T., Prusack, L. and Wilson, J. (2003), "Bringing you hot ideas and how are you responding?", Harvard Business Review, Vol.81, No.2, pp.58-64.

14. Davis, H., Evans, T. and Hickey, C. (2006), "A knowledge-based economy landscape: implications for tertiary education and research training in Australia", Journal of Higher Education Policy and Management, Vol.28, No.3, pp.231-244. https://doi.org/10.1080/13600800600979983

15. Desmet, A., McGulk, M.,and Schartz, E. (2010), "Getting more from your training programs", McKinsey Quarterly, No.4, pp.101-107.

16. Drucker, P. (1996), A gestão numa época de grande mudança, Lisboa: Difusão Cultural.

17. Edvinsson, L. and Malone, M. (1997), Intellectual Capital: Reusing your company's true value by findings its hidden brainpower, New York: Harper Business.

18. Garanina, T. and Pavlova, J. (2011), "Intangible assets and value creation of a company: Russian and UK evidence", In: Proceedings of the $3^{\text {rd }}$ European Conference on Intellectual Capital, University of Nicosia, Cyprus, 18- 20 April, pp.165-176.

19. Georgellis, Y. and Lange, T. (2007), "Participation in continuous, on-the-job training and the impact on job satisfaction: longitudinal evidence from the German labour market", International Journal Of Human Resource Management, Vol. 18, No. 6, pp. 969-985. https://doi.org/10.1080/09585190701321112

20. Guimarães, P. (2013), "Reinterpreting lifelong learning: meanings of adult education policy in Portugal, 1999-2010", International Journal of Lifelong Education, Vol. 32, No. 2, pp. 135-148. https://doi.org/10.1080/02601370.2012.733970

21. Guthrie, J., Ricceri, F. and Dumay, J. (2012), "Reflections and projections: a decade of intellectual capital research", The British Accounting Review, Vol. 44, No. 2, pp. 68-82. https://doi.org/10.1016/j.bar.2012.03.004

22. Hansson, B. (2007), "Company-based determinants of training and the impact of training on company performance: results from an international HRM survey", Personnel Review, Vol. 36, No.2, pp. 311-331. https://doi.org/10.1108/00483480710726163

23. Hermans, R. and Kauranen, I. (2005), "Value Creation Potential of Intellectual Capital in Biotechonogy: empirical evidence", $R \& D$ Management, Vol.35, No.2, pp.171-185. https://doi.org/10.1111/j.1467-9310.2005.00381.x

24. Huang, J. and Hyun Jeong, K. (2011), "Conceptualizing the processes, benefits, and challenges of organizational lifelong learning at Yuhan-Kimberly, Korea: the notion of anticipative affordance", International Journal Of Human Resource Management, Vol. 22, No. 7, pp. 1423-1441. https://doi.org/10.1080/09585192.2011.561958

25. Huang, C., Luther, R. and Tayles, M. (2007), "An evidence-based taxonomy of intellectual capital”, Journal of Intellectual Capital, Vol. 8, No. 3, pp. 386-408. https://doi.org/10.1108/14691930710774830

International Journal of Management and Applied Research, 2014, Vol. 1, No. 2 
26. Kaplan, R. and Norton, D. (2004), "Measuring the strategic readiness of intangible assets", Harvard Business Review, Vol.82, No.2, pp.52-63.

27. Lev, B. (2004), "Sharpening the Intangibles Edge", Harvard Business Review, Vol.82, No. 6, pp.109-116.

28. Levy, J. (2005), “The fourth revolution”, $T+D$, Vol.59, No.6, pp.64-65.

29. Liao, C., Songtao, M. and Grant, J. (2011), "Market implication of human capital investment in training", Academy of Accounting \& Financial Studies Journal, Vol. 15, No.2, Supplement, pp.59-87.

30. Liu, Q. and Wong, K. (2011), "Intellectual capital and financing decisions: evidence from the US patents data", Management Science, Vol.57, No.10, pp.1861-1878. https://doi.org/10.1287/mnsc.1110.1380

31. Loureiro, J. (2003), Gestão do Conhecimento, $1^{\mathrm{a}}$ edição, Lisboa: Inova.

32. Mehra, A. and Mookerjee, V. (2012), "Human capital development for programmers using open source software”, MIS Quarterly, Vol.36, No.1, pp.107-A5.

33. Mouritsen, J., Bukh, P. and Bang, H. (2005), "Understanding intellectual capital in a innovative medium-sized firm: the case of Maxon Telecom", Australian Accounting Review, Vol. 15, No. 36, pp. 30-39. https://doi.org/10.1111/j.1835-2561.2005.tb00287.x

34. Ng, I. and Dastmalchian, A. (2011), "Perceived training benefits and training bundles: a Canadian study", International Journal of Human Resource Management, Vol.22, No.4, pp.829-842. https://doi.org/10.1080/09585192.2011.555126

35. Nonaka, I. (2007), “The Knowledge: Creating Company", Harvard Business Review, Vol.85, No.7/8, pp.162-171.

36. North, K. (2010), Gestão do conhecimento: um guia prático rumo a empresa inteligente, Rio de Janeiro: Qualitymark.

37. OECD (2014), Portugal: Deepening Structural Reform to Support Growth and Competitiveness, Paris: OECD Publishing. https://doi.org/10.1787/9789264217270-en

38. Roos, G., Roos, J. (1997), "Measuring your company's intellectual performance”, Long Range Planning, Vol. 30, No. 3, pp. 413-426. https://doi.org/10.1016/S00246301(97)90260-0

39. Spender, J. (1996), "Making knowledge the basis of a dynamic theory of the firm", Strategic Management Journa1, Vol. 17, No: S2, pp. 45-62. https://doi.org/10.1002/smj.4250171106

40. Stam, C. (2007), Knowledge Productivity: designing and testing a method to diagnose knowledge productivity and plan for enhancement, The Netherlands: Twente University.

International Journal of Management and Applied Research, 2014, Vol. 1, No. 2 
41. Stewart, T. (1999), Capital Intelectual: A nova riqueza das organizações, Lisboa: Edições Silabo.

42. Sveiby, K. (2000), Capital intelectual: la nueva riqueza de las empresas: como medir e gestionar los activos intangíveis para crear valor, Barcelona: Gestion 2000.

43. Teh, C.; Kayo, E. and Mura, H. (2008), "Marcas, patentes e criação de valor", Revista de Administração Mackenzie, Vol.9, No.1, pp.96-106.

44. Tseng, C. and Goo, Y. (2005), "Intellectual capital and corporate value in an emerging economy: empirical study of Taiwanese manufacturers", $R \& D$ Management, Vol.35, No.2, pp.187-201. https://doi.org/10.1111/j.1467-9310.2005.00382.x

45. Wan, Z., Compeau, D. and Haggerty, N. (2012), "The effects of self-regulated learning processes on e-learning outcomes in organizational settings", Journal of Management Information Systems, Vol.29, No. 1, pp.307-339. https://doi.org/10.2753/MIS07421222290109 